\title{
PERBEDAAN ORIENTASI TUJUAN BERPRESTASI BELAJAR PENDIDIKAN JASMANI ANTARA SISWA ETNIS JAWA DAN ETNIS TIONGHOA \\ Dimyati
}

\begin{abstract}
This research is aimed at knowing the goal orientation difference of leaming achievement in physical education between students having Javanese ethnic background and those having Tionghoa one. The population of this research were the SMU students in Yogyakarta City. The ciuster random sampling technique was used by taking 320 students as the sample. The "TESQ" which developed by Duda \& Nicholls (1989) was employed as the data collecting technique to reveal variabel, of the goal orientation of learning achievement in physical education. Then student demography data was used to reveal variabel of ethnic background. The calculation result using $T$-test statistical analysis was $t=-14.294$ and $p=0.000$. The result constifuted the significant difference of the goal orientation of learning achievement in physical education between students having Javanese ethnic background and those having Tionghoa one. It means that the SMU students with Tionghoa ethnic background had higher goal orientation of tearning achievement in physical education than tihose with Javanese othnic background. Also, the students with Tionghoa background had higher goal orientation of learning achievement in physical education than those with Javanese ethnics background.
\end{abstract}

Key Words : achievement, physical education, students, Javanese, Tionghoa

\section{A PENGANTAR}

Kajian lintas budaya membandingkan siswa-siswa dari etnik atau latar belakang budaya yang berada di Amerika Serikat menunjukkan dan memberi makna bahwa prientasi tujuan berprestasi dalam bidang olahraga berbeda karena satu fungsi dari kebudayaan (Duda, 1986; 1989). Di sisi lain penelitian-penelitian d luar Amerika Serikat ditemuka bahwa ada kecen- derungan lebih menekankan pada tugas dan ego yang melibatkan tujuan-tujuan dan gabungan antara prestasi dan kepercayaan untuk berhasil. Penelitian ini tetap konstan pada latar belakang budaya yang berbeda dalam setting olahraga (Duda \& Templin, 1991; Duda \& Nicholls, 1992)

Hal tersebut di atas menunjukkan bahwa meskipun penelitian yang 
sesungguhnya difokuskan pada bagaimana tujuan-tujuan yang berbeda menimbulkan pola-pola motivasi yang berbeda pula, pertanyaan-pertanyaan penting mengenai motivasi berprestasi dalam pendidikan jasmani dan olahraga dari suatu perspektif antar etnik tetap tidak terjawab. Banyak perbandinganperbandingan dalam kajian lintas budaya yang difokuskan pada kelompok dan individu yang memiliki nilai-nilai yang konsisten dengan budaya Barat. Dengan demikian kajian lintas budaya terhadap siswa-siswa yang memiliki warisan atau latar belakang kebudayaan yang meng-gambarkan perspektif non Western atau non Amerika cukup menarik untuk diteliti. Penelitian ini akan mencoba mengungkap perbedaan orientasi tujuan berprestasi dalam belajar pendidikan jasmani antara siswa-siswa yang berlatar belakang etnik Jawa dan siswa yang berlatar belakang etnik Tionghoa. Diharapkan melalauti penelitian ini dapat diketahui sifat umum dari orientasi tujuan berprestasi dalam belajar pendidikan jasmani siswa SMU yang berlatar belakang etnik Jawa dengan siswa yang berlatar belakang etnik Tionghoa.

\section{B. TINJAUAN PUSTAKA}

\section{ETNOGRAFIORANGJAWA}

Orang Jawa adalah satu kelompok etnik yang mempunyai kebudayaan dan nilai-nilai maupun kebiasaan tentang sesuatu, yaitu kebudayaan Jawa (Koentjaraningrat, 1974). Suseno (1984) mengatakan bahwa di dalam pergaulan sehari-hari dan dalam tingkah lakunya orang Jawa mempunyai kaidah yang sangat menentukan : (1) dalam setiap situasi, manusia dikehendaki bersikap sedemikian rupa sehingga tidak menimbulkan konflik; dan (2) bahwa seseorang dalam cara berbicara dan membawa diri harus selalu menunjukkan sikap hormat terhadap orang lain sesıai dengan derajat dan kedudukannya. Kaidah yang pertama disebut sebagai prinsip kerukunan, dan kaidah yang kedua disebut dengan prinsip hormat. Kedua prinsip ini oleh orang Jawa dijadikan acuan bagi tingkah laku dan perbuatannya.

Mulder (1984) menegaskan bahwa dalam pandangan orang Jawa manusia tidaklah sendirian melainkan bagian yang tidak dipisahkan dari suatu kelompok. Manusia harus pasrah pada kekuasaan yang lebih tinggi dan menerima nasibnya disertai kesadaran bahwa hidupnya merupakan bagian dari masyarakat luas. Mulder mengatakan lebih lanjut bahwa etika duniawi oran Jawa dirumuskan sebagai "jangan merugikan orang lain". Karenanya setiap orang Jawa selalau menjaga jangan sampai terjadi konflik apalagi sifatnya terbuka. Usaha tidak terjadi konflik terlahir dari kesadaran untuk melawan hawa natsu, orang berusaha keras untuk mengekang diri sendiri. Kebiasaan ini menurut Sudigdo (dalam Mulder, 1984) menimbulkan sikap penuh kebaikan terhadap orang lain.

\section{ETNOGRAFI ORANG TIONGHOA}

Yudohusodo (1985) mengatakan bahwa orang Tionghoa merupakan pendatang yang jumlahnya paling banyak. Kedatangan orang-orang Tionghoa ko Indonesia membawa suatu norma-norma, adat istiadat, dan kebudayaan mereka sendiri. Sebagian orang Tionghoa yang tinggal di Pulau Jawa adalah orang-orang Hokkein, dan hidup dari berdagang (Vasanti, 1975; Suryadinata, 1986). 
Dalam masyarakat Tionghoa dikenal ada Tionghoa totok dan Tionghoa peranakan, sebagian besar orang Tionghoa yang tinggal di pulau Jawa adalah dari golongan peranakan. Mereka melakukan pernikahan campuran dengan penduduk setempat. Tetapi orientasi tersebut pada abad ke-20 mulai berubah, karena : (1) makin banyaknya imigran Tiongkok, dan imigran yang datang tidak lagi terdiri dari laki-laki, tetapi juga juga terdapat wanita. Merak tidak lagi kawin dengan penduduk pribumi; karena jumlah imigran Tionghoa lakilaki dan wanita seimbang. Keadaan ini menghambat proses akulturasi; (2) bangkitnya nasionalisme Tionghoa, memberikan kebanggan nasional yang kuat pada generasi baru imigran. Akbatrya mereka tidak lagi menyesuaikan diri dengan budaya penduduk asli, tetapi justru menghidupkan kebudayaan negeri leluhur.

Pandangan hidup dan filsafat orang Tionghoa sangat dipengaruhi ajaran ahli fikir seperti Taoisme yang dikembangkan oleh Lao, dan Khong $\mathrm{Hu} \mathrm{Cu}$ (Yudohusodo, 1985). Menurut Taoisme, yang terpenting dalam kehidupan ini adalah keluarga, dan kewajiban seseorang adalah selalu dihubungkan dengan keluarganya. Taoisme juga mengajarkan bahwa keluarga adalah sebagai tempat berlindung dari segala pengaruh luar, dan hubungan yang terjalin dalam keluarga sangat erat, sehingga tidak mudah untuk menerima pengaruh dari luar. Orang Tionghoa adalah suku yang paling Nasionalis di dunia, dalam arti mereka selalu menjaga kemurnian rasnya. Keadaan ini disebabkan adanya perasaan sebagai orang yang paling super dalam diri orang Tionghoa, dan mereka memandang rendah bangsa lain.
Berdasarkan ajaran Khong $\mathrm{Hu} \mathrm{Cu}$ (Hidayat, 1977) tiap-tiap individu harus mengembangkan kecakapan dan keterampilan semaksimal mungkin. Lebih jauh dikatakan bahwa sejak dari jarnan dulu pada orang Tionghoa sudah ditanamkan bahwa mereka adalah pusat pemerintahan dunia, maka dimanapun mereka berada haruslah melebihi tingkat hidup bangsa lain, akibatnya orang-orang Tionghoa suka bekerja keras, tekun, dan sabar serat hemat supaya tingkat kehidupannya menonjol. Ajaran-ajaran tersebut selalu dipegang teguh dan dibawa kemanamana serta dilaksanakan dalam segala aspek kehidupan dimanapun mereka berada. Sehingga dalam diri orang perantau Tionghoa selalau akan mempunyai kecenderungan untuk membentuk lingkungan sendiri dan hidup secara eksklusif.

\section{ORIENTASI TUJUAN BERPRESTASI DALAM PENDIDIKAN JASMANI}

Maehr den Nicholls (1980) mengatakan bahwa orang Tionghoa secara individu akan memiliki orientasi tujuan yang berbeda-beda. Pada manusia ada kecenderungan untuk menggunakan konsep-konsep keterampilan yang dimilikinya dalam merespons dan menginterprestasikan suatu peristiwa untuk mencapal apa yang disebut dengan achievement goals dengan cara berbeda-beda. Lebih lanjut Maehr dan Nicholls mengatakan bahwa penelitian tentang orientasi tujuan siswa harus dikaji secara kritis apabila para peneliti dan guru ingin memahami dan meningkatkan atau memperbaiki prestasi belajar siswa di sekolah.

Bukti-bukti empirik menunjukkan bahwa meskipun orientasi tugas dan orientasi diri keduanya melekat pada diri 
siswa, namun demikian orientasi tugaslah yang berkaitan dengan variabel motivasi yang sepertinya dapat meningkatkan atau memperbaiki waktu dalam belajar menjadi bermutu dan dapat berlangsung dalam jangka panjang. Menurut Duda dan Nicholls (1992), penelitian terhadap siswasiswa Amerika telah mendukung keberadaan orientasi diri dan orientasi tugas dalam konteks pendidikan jasmani dan olah raga. Duda, Olson dan Templin (1991) mengaskan bahwa hubungan-hubungan antara orientasi tujuan siswa dan keyakinan mereka, sama denga hasil observasi di kelas.

Duda (1989) mengatakan, beberapa penelitian yang dilakukan di luar Amerika ditemukan bahwa terdapat kecenderungan baik pada orientasi tugas maupun orientasi diri untuk mencapai tujuan tidak bisa lepas dari adanya keyakinan untuk berhasil atau dengan kata lain antara orientasi untuk mencapai tujuan dengan keyakinan berhasil saling terkait satu dengan yang lainnya. Keadaan ini berkangsung konstan dan berlaku terhadap berbagai kebudayaan yang berlainan dalam setting olahraga. Leung, Maehr dan Harnisch (1993) menguji perbedaan-perbedaan sosio kultural dalam orientasi motivasi akademik antara siswa-siswa Amerika dan Tionghoa Hongkong. Mereka menemukan bahwa siswa Amerika berpendapat tingkat kualitas tertentu yang lebih baik dalam melakukan sesuatu merupakan ukuran keberhasilan seseorang di kelas, sedangkan siswa-siswa Tionghoa menilai bahwa "berperilaku baik" sebagai suatu ukuran keberhasilan seseorang di kelas.

Orang Tionghoa yang tinggal di Indonesia mereka memiliki warisan yang sungguh bertainan dengan orangorang Jawa. Terdapat perbedaan dalam latar belakang berbagai dimensi budaya dan sosial antara orang Tionghoa Keturunan dan orang Jawa. Orang Jawa adalah satu kelompok etnik yang menganut kebudayaan dan nilai-nilai bahwa di dalam pergaulan sehari-hari ada dua kaidah yang sangat menentukan. yaitu menghindarkan sesuatu yang menimbulkan konflik terbuka dan harus selalu menunjukkan sikap hormat terhadap orang kin sesuai dengan derajat dan kedudukannya. Di lain pihak orang Tionghoa adalah suku yang paling nasionalis di dunia, dalam arti mereka selalu menjaga kemurnian rasnya. Ada tuntutan pada diri mereka, yaitu harus mengembangkan kecakapan dan keterampilan semaksimal mungkin. Pada diri mereka sudah tertanam bahwa orang Tionghoa adalah pusat pemerintahan dunia, maka di manapun mereka berada haruslah melebihi tingkat hidup bangsa laiin termasuk orang Jawa.

Perbedaan-perbedaan tersebut terimplementasi dalam perilaku kehidupan sehari-hari terutama dalam upaya mencapai sesuatu untuk menjalani kehidupan mereka termasuk di dalamnya adalah dalam bidang pendidikan. Kompetensi dengan siswa lain dalam bidang pendidikan merupakan sumber utama motivasi bagi para siswasiswa keturunan Tionghoa di Indonesia. Sedangkan suku-suku Jawa lebih menekankan kejasama, gotong royong, menjaga harmonisasi dengan kawan, juga kurang menekankan kompetensi dengan orang lain. Keadaan ini terbentuk pula dalam pola perilaku aktivitas jasmani termasuk di dalamnya orientasi tujuan berprestasi belajar pendidikan jasmani akan berbeda antara siswa yang berlatar belakang etnik Jawa 
dengan siswa yang berlatar belakang etnik Tionghoa.

\section{c. HIPOTESIS}

Terdapat perbedaan orientasi tujuan berprestasi dalam belajar pendidikan jasmani antara siswa yang berlatar belakang etnik Jawa dengan siswa yang berlatar belakang etnik Tionghoa. Siswa yang berlatar belakang etrik Tionghoa memiliki orientasi tujuan berprestasi belajar pendidikan jasmani yang lebih tinggi dibandingkan dengan siswa yang bellatar belakang etnik Jawa.

\section{METODE}

Penelitian ini mengggunakan metode survai dengan teknik angket. Angket digunakan untuk mengungkap variabel: (1) orientasi tujuan berprestasi dalam belajar pendidikan jasmani, dan (2) variabel siswa yang berlatar belakang etnik Jawa dan Tionghoa.

Kedua variabel tersebut didefinisikan: (1) orientasi tujuan berprestasi dalam belajar pendidikan jasmani, yaitu orientasi tujuan berprestasi siswa dalam belajar pendidikan jasmani yang mencakup indikator-indikator: kepuasan intrinsik, kesenangan, pemilihan tugastugas yang menantang, penggunaan strategi belajar yang efektif, ketahanan dalam menghadapi kesulitan, dan usaha-usaha meraih sukses. Variabel ini diungkap melalui instrumen yang dikembangkan dan dimodifikasi oleh Duda dan Nicholls (1989), yang dinamakan Taks and Ego Orientation Sport Questionare (TESQ); (2) siswa yang berlatar belakang etnik Jawa dan Tionghoa. Variabel ini menunjukkan latar belakang etnik siswa SMU yang berasal dari etnik Jawa atau Tionghoa yang diungkap melalui data demografi.

Angket TESQ disusun dalam model skala likert yang dimodifikasi dengan 5 (lima) alternatif pilihan yaitu STS (sangat tidak setuju); TS (tidak setuju); $\mathbf{R}$ (tidak dapat menentukan setuju atau tidak/ragu-ragu); S (setuju); dan SS (sangat setuju) yang diberikan kepada subjek penelitian dan subjek diminta untuk memilih salah satu jawaban yang tersedia yang benar-benar paling sesuai keadaan dirinya. Pernyataan angkat yang dipilij subjek, maka akan memperoleh skor 4 untuk jawaban SS; untuk subjek yang memilih alternatif $\mathbf{S}$, dia mendapat skor 3; subjek yang meimilih jawaban $\mathbf{R}$, di memperoleh skor 2, subjek yang memilih jawaban TS memperoleh skor 1; dan subjek yang memilih STS, dia memperoeh skor 0.populasi penelitian ini adalah siswa SMU se-Yogyakarta Kota. Teknik pengambilan sampel menggunakan cluster sampling. Teknik digunaka dengan langkah-langkah sebagai berikut : (1) menetapkan SMU yang mayoritas siswanya merupakan perpaduan antara etnik Jawa dan Tionghoa, (2) menetapkan proporsi sebesar 20 persen dari populasi siswa pada sekolah yang terpilih menjadi sampel, dan (3) menetapkan siswa sebagai subjek penelitian dengan cara acak. Berdasarkan ketiga langkah tersebut maka ditetapkan sekolah-sekolah yang menjadi sampel penelitian ini, yaitu sebagai berikut :

\section{Tabel 1}

\section{Daftar nama SMU dan Jumlah Subjek}

\begin{tabular}{|c|c|c|c|c|}
\hline \multirow{2}{*}{ top } & \multirow{2}{*}{ 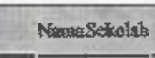 } & \multicolumn{2}{|c|}{ 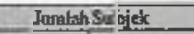 } & \multirow{2}{*}{ Junista } \\
\hline & & Fond & 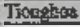 & \\
\hline l & Shu Ergutis & 60 & EA & 120 \\
\hline 2 & SMU Boofori D & 29 & 20 & 40 \\
\hline 3. & gatu Gella L hox & 59 & 59 & $100 \mathrm{~T}$ \\
\hline 4 & 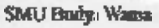 & 20 & 2111 & 40 \\
\hline \multirow[t]{2}{*}{5.} & Shlobinidi & 19 & 10 & $2[1$ \\
\hline & Eant't kpis & & & $3 \pi$ \\
\hline
\end{tabular}

Untuk memenuhi persyaratan alat ukur yang baik diadakan uj coba terlebih dahulu. Uji coba dilakukan pada sampel 
yang setara dengan subjek penelitian, yaitu siswa SMU of Yogyakarta Kota yang berlatar belakang etnik Jawa dan Tionghoa berjumlah sebanyak 80 siswa. Berdasarkan hasil uji coba instrumen menunjukkan bahwa vadilitas instrumen adalah $\mathrm{rtt}=0,879, p=0,000$. Reabilitas hasil uj coba menunjukkan bahwa dari 34 butir angket hanya dua yang gugur. Adapun rentang tingkat reabilitas butir angket berkisar antara $0,191-0,627$. Teknik analisis data untuk menguji hipotesis penelitian ini digunakan analisis uji t dengan menggunakan bantuan program komputer Seri Program Statistik (SPS 2000) Edisi Sutrisno Hadi dan Yuni Parmadiningsih UGM Yogyakarta.

\section{E. HASIL}

Analisis dengan teknik uji tdigunakan untuk mengetahui perbedaan orientasi tujuan berprestasi dalam belajar pendidikan jasmani antara siswa SMU yang berlatar belakang etnik Jawa dan siswa SMU yang berlatar belakang etnik Tionghoa. Terkait dengan analisis statistik ini ada prasyarat yang perlu dipenuhi, yaitu uj nomalitassebaran dan uji homogenitas. Hasil dari uji prasyarat tersebut, yaitu sebagai berikut:

Tabel 2

Rangkuman Hasil Uj Coba Normalitas

Sebaran Variabel

Orientasi Tujuan Berprestasi Selajar Penjas

\begin{tabular}{|c|c|c|c|c|c|c|}
\hline 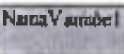 & 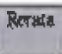 & $\begin{array}{c}\text { Kral } \\
\text { Kinstiot }\end{array}$ & $8 B$ & dh & $\mathbf{P}$ & KeI \\
\hline $\begin{array}{c}\text { Orlemiad } \\
\text { TuJuar } \\
\text { Berpresiafil }\end{array}$ & $8,6,69$ & 14,377 & 8\%क्र & 9 & 0,111 & ताबाmा \\
\hline
\end{tabular}

Tabel 3

Rangkuman Hasil Uji Homogenitas

Data Variabel

Latar Belakang Etnik Jawa dan Tlonghoa

\begin{tabular}{|c|c|c|c|c|c|c|}
\hline Surnber /Emik & dh & Eerria & Yhim & $F$ & $p$ & Stahk \\
\hline $\ln 14$ & 59 & 79006 & 4. 463 & \multirow{2}{*}{1,290} & \multirow{2}{*}{0,054} & \multirow{2}{*}{ homogen } \\
\hline Tiandwas & 159 & 98231 & 55562 & & & \\
\hline
\end{tabular}

Berdasarkan hasil analis is statistik dengan menggunakan uji t diperoleh data sebagai berikut.

Tabel 4

Rangkuman Hasil Perhitungan Variaber Orientasi Tujuan Berprestasi dalam Belajar Pendidikan Jasmani $(X)$

\begin{tabular}{|c|c|c|c|c|c|}
\hline Sugber & n: & $\Sigma_{X}$ & Rerits & $\begin{array}{l}A L-A^{2} \\
U_{2}=t\end{array}$ & $p$ \\
\hline Jang(AL) & 160 & 17641 & 78,116 & \multirow[b]{2}{*}{-14297} & \multirow[b]{2}{*}{0,000} \\
\hline $\begin{array}{l}\text { Thinghos } \\
\text { 'Atl }\end{array}$ & 160 & 44477 & 90.231 & & \\
\hline
\end{tabular}

\section{F DISKUSI}

Berdasar tabel 4 tersebut di atas ditemukan harga uji-t sebesar-14.297 dan $p=0,000$. Hasil ini berarti bahwa terdapat perbedaan yang signifikan antara siswa SMU yang berlatar belakang etnik Jawa dengan siswa yang berlatar belakang Tionghoa dalam orientasi tujuan berprestasi belajar pendidikan jasmani. Artinya bahwa siswa SMU yang berlatar belakang etnik Tionghoa memiliki orientasi tujuan berprestasi belajar yang lebih tinggi dibandingkan dengan siswa SMU yang berlatar belakang etnik Jawa. Kenyataan ini menunjukkan bahwa hipotesis penelitian yang berbunyi "Terdapat perbedaan orientasi tujuan berprestasi dalam belajar pendidikan jasmani antara siswa yang berlatar belakang etnik Jawa dengan siswa yang berlatar belakang etnik Tionghoa. Siswa yang berlatar belakang etnik T'ionghoa memiliki orientasi tujuan berprestasi belajar pendidikan jasmani yang lebih tinggi dibandingkan dengan siswa yang berlatar belakang etnik Jawa" dapat diterima.

Hasil pengujian hipotesis ini dapat dipahami karena menu rut Hiday at (1977) berdasarkan ajaran Khong Hu Cu tiaptiap individu harus mengembangkan 
kecakapan dan keterampilan semaksimal mungkin. Lebih jauh dikatakan bahwa sejak dari jaman dulu orang Tionghoa sudah ditanamkan bahwa mereka adalah pusat pemerintahan dunia, maka dimanapun mereka berada haruslah melebihi tingkat hid up bangsa lain. Ajaran-ajaran tersebut selalu dipegang teguh dan dibawa kemanamana serta dilaksanakan dalam segala aspek kehidupan dimanapun mereka berada termasuk tentunya dalam belajar pendidikan jasmani. Dengan demikian yang nampak pada orang Tionghoa di masa sekarang adalah yang rajin, tekun, hemat, memiliki semangat berusaha, dan suka bekerja keras, serta kadangkadang rasa superiornya masih nampak dalam berbagai aspek kehidupannya.

Latar belakang budaya dan ajaran orang Tionghoa sebagaimana tersebut d atas bertolak belakang dengan ajaran dan budaya orang Jawa . Suseno (1984) mengatakan bahwa di dalam pergaulan sehari-hari dan dalam tingkah lakunya orang Jawa mempunyai dua kaidah yang sangat menentukan : (1) dalam setiap situasi, manusia dikehendaki bersikap sedemikian rupa sehingga tidak menimbulkan konflik; (2) bahwa seseorang dalam cara berbicara dan membawa diri harus selalu menunjukkan sikap hormat terhadap orang lain sesuai dengan derajat dan kedudukannya. Kaidah yang dianut ini akan berimplikasi dalam kehidupan sehari-hari, di antaranya bisa jadi dapat mempengaruhi sikap kompetitif yang rendah dalam berbagai aspek kehidupan satu diantaranya dalam belajar pendidikanjasmani.

Mulder (1984) menegaskan, dalam pandangan orang Jawa manusia tidaklah sendirian melainkan bagian yang tidak dipisahkan dari satu kelompok. Manusia harus pasrah pada kekuasaan yang lebih tinggi dan menerima nasibnya disertai kesadaran bahwa hidupnya merupakan bagian dari masyarakat luas. Mulder mengatakan lebih lanjut bahwa etika duniawi orang Jawa dirumuskan sebagai "jangan merugikan orang lain". Setiap orang Jawa selalu menjaga sangan sampai terjadi konflik apalagi yang sifatnya terbuka. Usaha tidak terjadi konflik terlahir dari kesadaran untuk melawan hawa nafsu, orang berusaha keras untuk mengekang diri sendiri. Kebiasaan ini menurut Sudigdo (dalam Mulder, 1984) menimbulkan sikap penuh kebaikan terhadap orang.

Siswa SMU baik yang berlatar belakang etnik Jawa dan Tionghoa pada diri mereka masing-masing tidak akan terlepas dari budaya yang mendasarinya. Siswa SMU yang berlatar belakang etnik Tionghoa meskipun dilahirkan dan dibesarkan di lingkungan etnik Jawa, tapi sifat dan karakter mereka tidak akan luntur hanya karena faktor lingkungan. Teori konvergensi menegaskan bahwa kepri-badian seseorang ditentukan tidak hanya oleh faktor lingkungan, tapi juga oleh faktor keturunan atau heriditas. Dengan demikian adalah sesuatu yang wajar apabila siswa SMU yang berlatar belakang etnik Jawa memiliki orientasi tujuan berprestasi lebih rendah dalam belajar pendidikan jasmani dibandingkan dengan siswa yang berlatar belakang etrik Tionghoa.

Perbedaan-perbedaan tersebut terimplementasi dalam perilaku kehidupan sehari-hari terutama dalam upaya mencapai sesuatu untuk menjalani kehidupan mereka termasuk di dalamnya adalah dalam bidang pendidikan. Kenyataan menunjukkan bahwa orang tua orang tua Tionghoa sangat selektif dalam menentukan pilihan sekolah yang dimasuki anak-anak mereka. Kompetensi 
dengan siswa lain dalam bidang pendidikan merupakan sumber utama motivasi bagi para siswa-siswa keturunan Tionghoa di Indonesia. Di sisi lain, sukusuku Jawa lebih menekankan kerjasama, gotong royong, menjaga harmonisasi dengan kawan,juga kurang menekankan kompetensi dengan orang lain. Keadaan ini terbentuk pula dalam pola perilaku aktivitas jasmani dan olahraga termasuk di dalamnya orientasi tujuan berprestasi belajar pendidikan jasmani akan berbeda antara siswa yang berlatar belakang Jawa dengan siswa yang berlatar belakang etnik Tionghoa.

\section{G. PENUTUP}

\section{KESIMPULAN}

Berdasarkan hasil penelitian dan pembahasan dapat disimpulkan bahwa terdapat perbedaan orientasi tujuan berprestasi dalam belajar pendidikan jasmani antara siswa yang berlatar belakang etnik Jawa degan siswa yang berlatar belakang etnik Tionghoa. Siswa yang berlatar belakang etnik Tionghoa memiliki orientasi tujuan berprestasi belajar pendidikan jasmani yang lebih tinggi dibandingkan dengan siswa yang berlatar belakang etnik Jawa.

\section{SARAN}

Berdasarkan hasil penelitian ada beberapa saran yang dapat disampaikan diantaranya adalah sebagai berikut:

a. Para guru Pendidikan Jasmani untuk lebih memahami latar belakang etnis siswa sehingga mereka termotivasi belajar dengan sungguh-sungguh. Melalui upaya ini diharapkan proses belajar mengajar dapat berlangsung dengan lebih efektif.

b. Penelitian lebih lanjut perlu memperhatikan faktor-faktorlain, misalnya minat pada pelajaran Pendidikan
Jasmani, konsep diri, persepsi terhadap Pendidikan Jasmani, atau efikasi diri guru.

\section{DAFTAR PUSTAKA}

Ames, C. 1992. Clasroom : Goal, Structure, and Student Motivation, Journal of Educational Psychology. $84,261-272$.

Ames, C., \&Ames, R. 1981. Competitive Versus Individualistie Goal Structure : The Sailence of Past Performance Information of Causal Attribution and Afect. Journal of Educational Psychology, 73, 411-418.

Brooke, G.A. 1981. Perspective on The Academic Disipline of Physical Education. Ilionis : Human Kinetics Publisher.

Bucher, C,A, Wuest, D., 1995. Foundation of Physical Education and Sport. New York: Mosby.

Duda, J.L. 1986. Perception of Sport Sucsess and Failure among With Black and Hispanic Adolescents. In J. Watkins, T.T. Reilly, \& L. Burwitz, eds. Sport Science. London : E. \& F.N.Spon.

Duda, J.L. 1989. Relationship Between Task and Ego Orientation and The Perceived Purpose of Sport Among High School Atheletes. Journal of Sport \& Exercise Psychology, 11, 318-335.

Duda, J.L. \& Nicholls. J G. 1992. Dimension of Achievement Motivation in Schollwork and Sport. 
Journal of Educational Psychology, $84,290-299$.

Duda, J.L.1991. The Relations Between Task and Ego Orientation to Sportmanship Attitude and the Perceived Legitimacy of Injurious Act. Research Quarterly for Exercise and Sport, 62, 79-87.

Hidayat, Z.M. , 1997. Masyarakat dan Keetnikan Tionghoa dan Indonesia. Bandung : Tarsito.

Kodiran. 1975. Keetnikan Jawa dalam Koentjaraningrat (Editor). Manusia dalam Keotnikan di Indonesia. Jakarta ; Jambatan.

Koentjaraningrat. 1974. Keetnikan Mentalitet dan Pembangunan. Jakarta: PT. Gramedia.

Leung, J., Maehr, M.L., \& Harnich, D.L. 1993. Some Sosiocultural Difference in Students Achievement Motivational Orientation. Journal of Personality and Social Psychology. 4, 793-804.

Maehr, M.L., \& Nicholls., J.G. 1980. Culture and Achievement Motrvation: A Secon look In M. Warren (Eds). Studies in Cross Culture Psychology (peraturan 221-267). New York :Academy Press.

Mulder, N. 1984. Kebatinan dan Sikap Hidup Sehari-hari Orang Jawa . Jakarta : PT. Gramedia.

Nasution, S., 2001. Metode Research (Penelitian /Imiah). Jakarta : Bumi Aksara.
Saifuddin Azwar., 2001. Metode Penelitian. Jogjakarta : Pustaka Pelajar.

Siswono Yudohusodo. 1985. Warga Barat. Jakarta : PT. Gramedia.

Suryadinata, L. 1986. Dilema Minoritas Tionghoa. Jakarta : Grafiti Press.

Suseno, F.M. 1984. Etika Jawa. Jakarta :PT. Gramedia.

Vasanty, P. 1975. Keetnikan Orang Tionghoa Indonesia dalam Koentjaraningrat (Editor). Manusia dan Keetnikan di Indonesia. Jakarta : Jambatan.

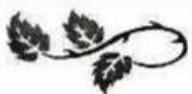

